\title{
Cultural Assimilation: Two Ibsenian Women in Traditional Chinese Yue Opera
}

\author{
TERRY SIU-HAN YIP
}

\begin{abstract}
Chinese interest in Henrik Ibsen's plays has flourished for more than a century and many of his plays have been performed on or adapted for the Chinese stage since the early twentieth century. However, attempts to adapt his plays for the traditional Chinese theatre were only made in the past decade with Peer Gynt adapted into Peking opera in 2006, The Lady from the Sea and Hedda Gabler into Yue opera in 2006 and 2010. A close study of the re presentation of two Ibsenian women characters, namely, Ellida Wangel and Hedda Gabler on the Chinese traditional Yue operatic stage during Ibsen's centenary in 2006 reveals the Chinese cultural assimilation of the two Norwegian women with their distinct character and outlook of life to suit the traditional Chinese notion of femininity and morality, as well as the conventionality of the Yue theatre with its unique theatrical and aesthetic considerations. What is more important is the Chinese desire to invite the audience, especially the young audience, to reconsider what constitutes happiness and integrity for married women in the Chinese context with an emphasis on moral responsibility.
\end{abstract}

Keywords: Ellida Wangel; Hedda Gabler; self; gender; individuation; Confucianism; Yue opera; Henrik Ibsen

It is a known fact that Henrik Ibsen has openly questioned the validity of prevailing gender norms affecting women in Norway in late nineteenth century and has created a number of romantic women characters who feel trapped in their marriages or ineffectual in their restrictive gendered roles. Ellida Wangel and Hedda Gabler, for example, are no ordinary wives who adhere dutifully to their gender roles. Instead, they are presented as women with a heightened sense of self, who struggle for the liberation of the female self, for proper recognition in gender relations and for self-fulfillment in a stifling socio-moral environment which expected married women to conform and perform, to borrow Judith Butler's term, according to prevailing gender norms. In Lady from the Sea and Hedda Gabler, Ibsen delineates Ellida and Hedda's process of individuation as they attempt consciously to break away from their performative gender roles with the feminine attributes desired by men at the beginning of the plays to 
YIP

become women of determination in seeking freedom and in preserving their integrity as responsible individuals at the end. Both Ellida and Hedda have been well known in world drama as unwomanly women whose battle for self realization has prompted them to transgress prevailing gender norms that expected women to assume a passive and subordinate position in marital relationships. What these two Ibsenian women share in common is their romantic dream and their secret love affair in the past that continue to haunt them after marriage. Ellida has been fascinated by the Stranger's adventurous life and free spirit for he represents a world of indefinite possibility, while Hedda has been emotionally attached to Lovborg the romantic drifter and free agent who has become a distinguished scholar. The domestic setting in the two plays is presented as the locus of power relations between men and women with the latter consciously struggling to break from their stifling lives of domesticity characterized by their feminine sense of duty and familial/moral conscience to embark on a life of their own defined not by their gender roles but by their sense of honour, moral responsibility and integrity - qualities that were often considered as unwomanly at Ibsen's time.

\section{Transplanting Ellida and Hedda on the Chinese Soil}

When Ellida and Hedda, as two non-conforming Ibsenian women characters, were transplanted to China and presented on the Chinese Yue opera stage in 2006, they have undergone drastic cultural transformation in terms of personality and outlook of life. Such changes are deemed necessary for the purpose of cultural assimilation and for adherence to the Chinese notion of femininity, as well as the conventionality of the traditional Yue theatre with its distinct theatrical and aesthetic features. What interested the Chinese Yue theatre goers most are the two Ibsenian women's moral dilemmas and subsequent choices and how such individual quests for love, autonomy and selfrealization can be represented in traditional Chinese opera.

The operatic form of the traditional Yue theatre has been chosen for the purpose of adaptation because of its soft and leisured singing style, elegantly written lyrics and graceful stage dance or movement, which makes it the ideal theatrical form to deal with love stories of the "caizi jiaren" (the talented scholar and the charming lady) tradition. As a form of Chinese opera founded in Shengzhou in the Zhejiang Province in 1906, Yue opera has distinguished itself since the 1930s as a women's opera employing an all-female cast (Jin Jiang 2009: 5): 
Yue drama is a soft and beautiful feminine opera ... that is performed by women and is good at telling women's stories. It is women's favorite opera. ... The fact that the young male role is played by women determined that the main theme of Yue drama is the love story and soft beauty is its main style. (Quoted in Jin Jiang notes.)

The all-female cast makes scenes of physical intimacy possible and less embarrassing on the Chinese stage. The poetic lyrics also facilitate the dramatization of the characters' complex psychological states and emotional intensity. It is thus not surprising to find that the Chinese adaptations of The Lady from the Sea (or Haishang furen), performed by the Hangzhou Yue Opera Company and Hedda Gabler (Xin bi tian gao), performed by the Shanghai Yue Opera Company in 2006, focus on the triangular love relationships between Lida [Ellida] and her romantic sailor-lover Jiang Siteng [the Stranger] and her gentle and caring husband Dr Fan Ge [Dr Wangel] in Haishang furen and the lovehate relationship between Haida [Hedda] and her learned former lover Wenbo [Lovborg] and her mediocre husband Simeng [Tesman]. Instead of taking the common approach adopted by most of the critics in scrutinizing the additions or deletions of scenes, the use of symbols and colours and characters' theatrical performances in the Chinese operatic adaptations, this paper will focus on the re-presentation of Ellida and Hedda as classical Chinese women in traditional Yue opera, which often celebrates the Confucian values of decency, morality and propriety.

\section{Lida and the White-Clothed Narrator in Haishang Furen}

Different from Ibsen's use of the retrospective technique, the Yue operatic adaptation of The Lady from the Sea presents Lida's romantic love, emotional anxiety and moral dilemma in chronological time in order to suit the Chinese mode of narration. Throughout the entire Yue opera, Lida is accompanied by a nameless white-clothed female character who functions as a detached observernarrator, as well as a commentator. Witnessing Lida's emotional crises and psychological turmoil, the nameless white-clothed observer-narrator provides the audience with the proper perspective to Lida's decisions and actions on the one hand and concretizes Lida's moral dilemma and troubled mind through songs and dances. The white-clothed character offers the audience her interpretation or understanding of the incidents unfolding on the stage. The fact that she is presented as the one who moves freely between Lida's romantic dream of love and happiness and Lida's state of anxiety and confusion in reality 
YIP

allows the Chinese Yue opera to bring out the interplay between Lida's past with the present as well as between her romantic self and moral being. Some critics such as Ye Ning consider the presence of such a white-clothed observernarrator quite unusual in traditional Chinese opera (Ye 2011: 21), but there actually exists in classical Chinese literature a long tradition of stories narrated by a storyteller or narrator who also serves as commentator. Viewed in this light, the nameless female observer-narrator can be regarded as a creative deployment of the "bangqiang," in traditional Chinese opera whose function is comparable to that of the chorus with the aim of elucidating the psychological and emotional complexities of Lida's life in the Chinese Yue opera.

\section{Lida's Romantic Love and Her Moral Considerations}

By introducing Lida as a young woman who waited earnestly for her sailorlover Jiang Siteng near the seaside in the opening scene, the Chinese Yue opera creates a culturally acceptable narrative for its Chinese audience who are used to a tradition of narratives presented in a chronological way. Different from Ellida, who enters into a symbolic marital bond with the Stranger in a passive way by allowing the Stranger to tie their rings together and throwing them into the sea, Lida in the Yue opera is the one to initiate a spiritual wedlock - a seal of devotion - with Jiang before her sailor-lover's departure. This slight change of the plot transforms the Ibsenian woman who is known as a dying mermaid stranded on land to become the passionate Lida, who seeks love and happiness actively by initiating the symbolic wedlock. Using a red string, which reminds the audience of the Chinese mythological god of marriage whose job is to tie lovers' feet together with a red string on the day of their births to secure their love fate, Lida expresses her determination to set her own fate and shows her devotion to her sailor-lover. Such a symbolic act of love bond reveals Lida's daring character and romantic temperament on the one hand and her virtuous and sincere attitude typical of the female leading character in traditional Chinese Yue opera on the other.

With Lida's vow of love and her spiritual wedlock with Jiang, the love theme in the "caizi jiaren" tradition, together with the dream-like quality of romantic love, is firmly established in the opening scene. Lida's sense of morality is brought into the limelight in the following scene when the audience learns that she has kept her promise and waited for ten years with no news from Jiang. Such a long period of waiting provides the morally acceptable ground for her marriage to a widower Dr Fan in the Chinese Yue opera. As Lida commented on her marital decision, she "was losing her mind and could go on no more": 


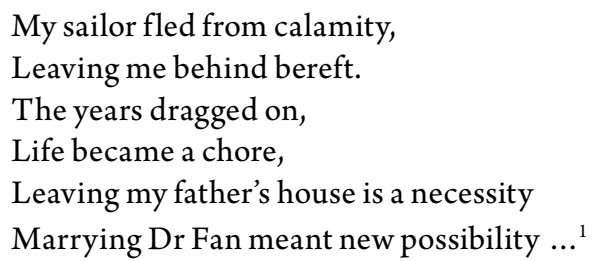

Lida offers the audience three good reasons for breaking her love vow. Since she has not heard any news from her sailor-lover for ten years, Lida has all the reasons to believe that Jiang might have drowned in the perilous open sea. As a conscientious and dutiful daughter, Lida finds it her duty not to bring embarrassment or gossip to her paternal home by staying single in her father's house after she has come of age. Furthermore, the widower Dr Fan seems to be the best possible choice for her with his gentry background and respectable profession. Thus Lida's marriage to Dr Fan is presented not as a breach of her love vow or devotion to her absent sailor-lover but as a sign of her conscientious demeanor and moral responsibility, which are socially acceptable and morally desirable in the Chinese cultural context.

\section{Lida's Romantic Dream versus her Confucian Virtues}

Unlike Ellida the dying "mermaid" finding herself stranded on land and feeling alienated and dislocated in Wangel's family, Lida in the Chinese Yue opera has accepted her new roles as Dr Fan's second wife and Bolai's stepmother and has acclimatized herself in Dr Fan's family with her romantic love buried. It is repeatedly emphasized throughout the Yue opera that Lida has put aside her romantic love after her marriage and that her subsequent motherhood has strengthened her sense of belonging to the Fan family. As noted by the observer-narrator, "Time seemed to have mended her broken heart" and "motherhood has held her kindly in the moment... The birth of a child has taken Lida's mind away from her past" and "she has settled down to a new life with Dr Fan." The sudden death of her son, however, comes as a great blow to Lida, unsettling the core of her being and reminding her of those by-gone days of love, happiness, and freedom:

1 The English translation of the Chinese Yue adaptations of The Lady from the Sea and Hedda Gabler quoted in this paper follows the English subtitles done by Sun Huizhu and Fei Chunfang. 
But losing my son has opened a gaping hole inside...

Here away from the island, I put the sea out of my mind.

But in my child's last hours, I saw the blue sea in his eyes.

Her tormented soul is vividly presented through the re-enactment of her parting scene with her sailor-lover Jiang in the past, together with her remorse over his long absence, the recent death of her son, and her "encounter" in a dream with her sailor-lover, who accuses her of breaking her vow of love. In the Yue opera, it is Lida's sense of propriety and morality that is emphasized in her hysterical dance and soliloquy in which she expresses her loss of her son and fear of her sailor-lover's return. As Lida confides in Dr Fan when the latter suggested moving the family to the island for the sake of her health:

LIDA: I was once betrothed to someone else.

Returning home [the island] may stir up the past."

Such a portrayal of Lida as a conscientious person places her among the conventional good and virtuous wives in the Chinese Confucian tradition. Her peaceful marital relationship with Dr Fan, however, is unsettled by the unexpected return of her sailor-lover Jiang. Lida finds herself torn between the two men whom she holds dear in life. As the narrator observes, Lida is swept off her feet with Jiang returning to claim her, thus "bringing turbulent currents to her haven," as well as putting her sense of propriety, integrity and morality to a test. As the observer-narrator comments, "With the past catch up with the present, will the old flame be rekindled?” Uncertain about her own feelings for her former lover, Lida comes to fear that her sound moral judgement might be taken over by her destructive passion. As she states openly her moral position when Anhong informs her of Jiang's return:

Tell him not to look for me.

Time has changed. We're not who we were before.

[cried]

The past returns like a ball of fire

Fanning quiescent embers to flame.

I am drawn to the fire, but

Fearful of its destructive powers.

......


Cultural Assimilation

Not a word for so many years

Why force your way back into my heart

A sailor always wants to roam free

The past should stay in its place.

Her remarks cited above show that Lida, as a mature married woman, has come to see her carefree life and passionate love in the past as nothing more than a romantic dream, a destructive force that can easily consume a person's moral being and sensibility. As evidenced in the Yue opera, Lida finds Jiang's tender words of unfading love alluring and irresistible. His sweet words of love have "plucked the strings of her heart," leaving Lida lost in a moral dilemma. Jiang's earnestness has further prompted Lida to reflect on her "long lost love" and carefree days in the past, comparing it with her stable married life in "her devoted family," as the narrator relates in a succinct way.

In order to conform to the conventionality of the Yue operatic tradition, it is noticed that the Ibsenian woman's personality has been reconstituted with her Confucian virtues and sense of morality emphasized. As is pointed out by Jiang after his attempted elopement with Lida, "the little lady is so full of virtues, believing in rule and decorum." From a devoted maiden who has kept her love vow for ten years, Lida has become a responsible wife and caring stepmother after marriage. As evidenced in her sound advice on love and marriage to her stepdaughter Bolai, Lida comes to understand the difference between infatuation and true love, between loving a man's adventurous life at sea and loving the man as a person. Lida has agreed to elope with Jiang not because of her personal desire for romantic love but because of her wish to save Jiang's life. She urges Jiang to honour his "gentleman's pact" with Dr Fan and let her decide to stay or to leave in the morning instead of sneaking away in the middle of the night.

Her sense of righteousness is heightened when Lida gets lost amidst the maze-like mountain trails. Regarding it as a kind of retribution for her misconduct and ingratitude, she urges Jiang to take her home so that she can show Dr Fan her gratitude and respect properly even if she eventually chooses to leave her husband. Viewed in this light, the confrontation between Jiang Siteng and Dr Fan dramatizes not so much the dilemma of choice Lida is forced to face as the legitimacy of her relationship with the two men according to Confucian morality and socio-moral practices:

JIANG [sailor]: I am asking you for permission to take Lida with me.

FAN [doctor]: Lida is my wife.

JIANG [sailor]: But she was engaged to me. Lida was mine first.

FAN [doctor]: But now she is my wife. 
JIANG [sailor]: A well-educated man, how can you take another man's wife? FAN [doctor]: Who is taking another man's wife? Were you married by your parents' wishes? Or on a match-maker's word?

JIANG [sailor]: We made our own match and vowed to love each other forever.

FAN [doctor]: Lida married me and moved here out of her own free will, and she's never mentioned being your wife.

JIANG [sailor]: Dr Fan, in your profession as a doctor, it's your duty to heal and help people. Can you see what's causing Lida's heartache?

FAN [doctor]: I'll ask Lida to come. We'll find out.

It is noteworthy that Jiang's recklessness and earnestness are juxtaposed against Dr Fan's sensibility and well-considered response. In the Yue opera, Dr Fan is associated with the stable and lofty mountain that enables a traveler to see clearly his or her "path" ahead. His consideration of Lida's marital state, coupled with his nobility and sensibility as a person, provides Lida with a proper perspective for viewing her emotional condition and psychological disturbance. Lida is led to see her own situation in a new light. As she admits, she has undergone a spiritual journey and has experienced an epiphany while she was groping her way in the ancient mountain:

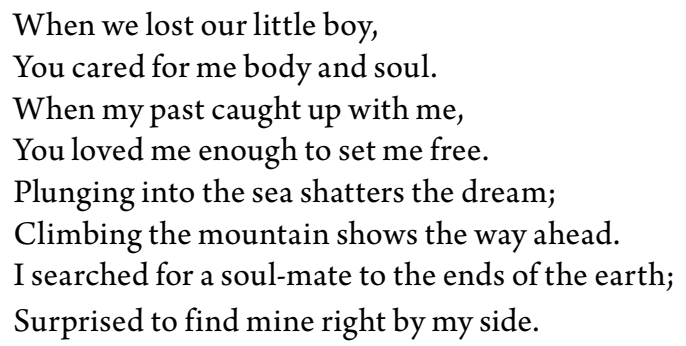

In her moment of epiphany, Lida realizes her moral blindness. The spell of the sailor-lover, with his adventurous life and romantic love, is gone as Lida realizes what she seeks in life is happiness and self-actualization achieved not through her attachment to any man but through a process of individuation which allows her to make sensible moral choices in life. She sees her folly in the past when she tried to realize her self through a man and through her dream of finding a soulmate, who will complete her. Her dream of romantic love is now understood by Lida as an illusion comparable to the Buddhist notion of seeking "the moon in the water" or trying to get "the flower in the mirror."

Lida's realization of her indulgence in a prolonged or extended romantic dream represented by her sailor-lover Jiang, and her ultimate awakening from 
her state of spiritual inertia proves to be the redeeming force, saving Lida from her emotional agony, psychological anxiety and self- ineffectuality, As seen in the Chinese rendition of the Norwegian play, Lida succeeds in resisting "temptation" presented in the form of romantic love through a process of individuation during which she comes to see her own worth and her position in the Fan family and the world. Viewed in this light, Lida's decision to stay with her loving and caring husband signifies the Chinese affirmation and glorification of feminine virtues defined not so much by a heightened sense of the individual self as by a better understanding of one's self characterized by Confucian decorum and righteousness and an awareness of moral goodness. As Lida observes at the end, home is the place where one's heart belongs and since she has married Dr Fan, his home is the place where her heart resides. Such an affirmation makes Lida an upholder of feminine virtues and Confucian morality and an exemplar of Chinese womanhood. As the whiteclothed observer-narrator sums up at the end, "If a woman's heart has gone off course, who will be able to get her back" but her own good moral sense. Such a treatment of Ibsen's Ellida shows how the Ibsenian woman has been successfully transformed for the traditional Chinese Yue theatre to embrace not a woman's quest for romantic love but her attainment of moral goodness.

\section{Haida's Unfulfilled Self and Choice of Marriage Partner in Aspiration Sky High}

In a comparable way, the treatment of Hedda in the operatic adaptation of Hedda Gabler by the Shanghai Opera Company in 2006 follows a similar vein. In the Yue opera adaptation entitled Aspiration Sky High (Xin bi tian gao), Haida is presented as a romantic dreamer, an active seeker of love and happiness in life. Being the daughter of a school principal, Haida appears as an arrogant and manipulative woman, who takes pride in her knowledge of classical texts and swordsmanship. She ranks her own ability and intelligence above most of her father's students, including her husband Simeng, but she finds herself trapped in her gendered roles and her life unfulfilled as there is no way for a woman to actualize herself except through her husband. Haida's frustration is further intensified when she finds herself caught in a joyless marriage with Simeng, a weakling-scholar whom she despises for his mediocrity and unmanliness. The dream motif one finds in Haishang furen is also found in Aspiration Sky High (Zhang Xinying 2007: 75). The idea that love is but a dream sets the overall tone for Aspiration Sky High with Haida's dream of her former lover Wenbo. Her dance with a pair of "yinyang" (embodying the male and female 
principles) swords, which is her love token with Wenbo in the past, at the opening scene of the Yue opera reveals Haida's reminiscence of her past love, her agony or remorse caused by her boring husband, and her frustration over her entrapment in a joyless marriage and an unfulfilled life with Simeng, who fails to understand her needs or to live up to her expectation.

As is elucidated at the beginning of the Chinese Yue opera, Haida's unfeminine hobby of playing with her paired swords is met with disapproval and criticism from her husband, who keeps reminding her of a woman's performative and feminine roles such as washing clothes, cooking, gardening, or playing musical instruments. It should be noted here that while Hedda in Ibsen's play has married Tesman out of impulse and a casual promise, thinking that Tesman might eventually become a prominent scholar, Haida's marriage to Simeng in the Chinese Yue adaptation has been an arranged one with Master Bai serving as the match-maker. This modification of the plot accentuates Haida's trapped situation and immediately places her amongst the obedient Chinese daughters, who might have secretly dreamed of romantic love in their maiden days but have seldom dared transgress socio-moral norms for fear of jeopardizing their own reputation or the honour of the family. Haida believes that she has had all the good reasons for jilting Wenbo in the past for his moral delinquency:

He was easily charmed by women
He defied all conventions
He indulged in hard drinking
He wasted his talent and learning

Her pride is deeply hurt, however, when Wenbo reappears in her life as a morally redeemed person and a highly acclaimed scholar. What troubles Haida doubly is Wenbo's preference for Haida's cousin Siya, who is the Chinese rendition of Mrs Elvsted. Portrayed as a widow in the Yue opera, Siya's elopement with Wenbo is viewed as plausible and acceptable in the Chinese socio-cultural context. Siya's simplicity, sincerity and faith in her man are presented as desirable feminine traits that help bring out the best qualities in any man, while Haida's suspicious character and selfish, schematic and manipulative personality are regarded as unwelcoming unfeminine features that tend to drive any sensible man away. Instead of admitting her own mistake in choosing her partner in marriage, Haida accuses Wenbo of misleading her, causing her to take Simeng as her husband:

Why were you like drifting duckweed and not a tall shady tree?

Why did you ignore good counsel and make my love impossible? 
It is apparent from the Yue opera that Haida and Wenbo would have made an ideal couple just like the perfect pair of "yinyang" swords if not for Haida's vanity, pragmatism and selfishness. As Haida recalls her past relationship with Wenbo,

We met and fell in love,

Sharing and pursuing mutual passion.

A pair of swords.

A pair of lover.

Under the moon and among the flowers.

But his irresponsible ways grew,

So I left and married someone else.

No news since the break-up (two years' ago).

Pining for him nearly drove me mad;

Now things have changed so much.

The reunion only brought more hurt.

As a willful and domineering woman, Haida's choice of Simeng, the stable but unmanly man as her husband, is doomed. As Master Bai rightly observes, Simeng is so stable and solid that one cannot "make a dent in it" and "surely he is not as exciting as Wenbo.” Being a romantic dreamer, Haida can never feel content in her marriage with a bookish man. She is fully aware that her chance of happiness in life is slim and feels herself betrayed when Wenbo reappears as a prominent scholar:

The one I've dreamed of is here.

Sweet talks still lingering in the air.

Heart and head fight;

Love and Hate mingle.

Her remarks above clearly show Haida's remorse and regret, as well as her selfpity. Disillusioned in life and frustrated by Simeng, who turns out to be a failed scholar and boring husband, Haida laments her wrong choice and her bleak future:

The world is full of uncertainties.

It's always hard for a woman.

It's always hard to tell a genius from a rake.

It's always hard to tell a promise from a lie.

It's always hard to reel back time.

It's always hard to quell one's remorse.

It's always hard to make the right choice. 
Why does a capable woman need to depend on a man?

Why is my fate thus sealed?

In a desperate and hysterical state after Wenbo decides to have their past love buried, their love-token sealed and their paired swords returned to their case now that he is in love with Siya and Haida has married Simeng, Haida vents her anger and agony openly. She is determined to take revenge for she is overwhelmed by her jealousy and remorse: "I swear by this sword I'll see you fail in love and in career."

\section{Haida's Individuation Through Self-Knowledge and Self-Preservation}

It is her bitterness, hurt pride and intense jealousy that prompted her to embark on a road of no return. Haida is eager to strike back, thinking that she can reverse her fate by her schematic tricks and her manipulative power over others. She regards Wenbo's book manuscript as a mockery of her own folly, vanity and fate that has to be destroyed. Being so used to getting her own way in life by exercising her charm and power, Haida tries all means to secure her husband's career advancement since her own fate has been tied to his after marriage. Her burning of Wenbo's book manuscript can thus be interpreted as a manifestation of Haida's flame of jealousy that devours her entire being. She is willing to pay any price to change her fate by securing a position for Simeng at court. In doing so, she also wants to let everyone know that her choice of Simeng has been the right one.

\section{Haida's Pride and Sense of Honour}

To her surprise, Haida finds her scheme shattered when Simeng decides to team with Siya in restoring the burnt manuscript after Wenbo's ignoble death. With her husband's renewed affiliation with Siya, Haida finds to her alarm that she is left alone at the mercy of the evil Master Bai, who tries to harass her sexually and threatens to reveal her "crime" to the officials. It dawns on Haida that all her efforts to improve her husband's career prospect and to change her own fate have been futile. She is left with nothing in life but her hurt pride and a shattered self: 
Cultural Assimilation

I did everything to secure your [Simeng's] future.

You send me to danger.

Playing with fire and got burnt

Hurt myself as a well as others

She comes to see her own entrapment in a hopeless situation and hellish existence with no way out:

Wenbo, you rid the mundane life at last.

With a masterpiece lauding the best.

While you rest in your carefree dream,

I'm lost in my hellish doom.

This moment of self-knowledge comes at the end of her painful process of individuation. Acknowledging the fact that she has always been a victim of her own self-love, of her romantic dream, of her vanity and of her desire for fulfillment and happiness in a world hostile to women with aspiration, Haida is determined to be her own "master" and take her fate in her own hands by killing herself with the paired sword. As she admits at the end,

I lived for love; it broke my heart.

I lived for fame, it cist my soul.

I lived for self-interest, it burnt me to ashes.

Viewed in this light, Haida's suicide at the end is consistent with her incessant quest for freedom and self-realization. Instead of succumbing herself to perpetual sexual abuses and a life of remorse, Haida chooses to free herself from her entrapment in love and marriage and to save herself from Master Bai's sexual advances through death, which can be seen as a form of protest against the confining patriarchal system from a woman with aspiration and a refuge for a soul lost in despair.

Through careful delineations of Lida and Haida's moral crises and troubled selves, the Chinese Yue adaptations succeed in drawing the audience's attention to the imbalance of gender relations that tend to confine women to a life of domesticity. Women's frustration and despair as witnessed in their trapped conditions and their struggles for change in the two operas reveal the haunted lives of married women who have to realize themselves through men. Lida's decision to stay at home with her husband Dr Fan and Haida's suicide at the end signify women's failure in striking a balance between their romantic dream of love and self-actualization and their socio-moral awareness of their gender roles and subordinate positions in a tradition-ridden society. In face of moral 
crises, both Lida and Haida are forced to re-examine their gendered lives, their problematic marital relationships, and their troubled selves and to undergo a painful process of individuation. Lida eventually comes to understand that her sailor-lover represents her romantic dream for freedom and independence. With Dr Fan's unconditional love and faith in her, Lida is saved from a false, distorted and perilous mode of being at the end.

In a comparable way, Haida's suicide at the end can also be interpreted as an intelligent woman's refusal to succumb herself to a life of falsehood epitomized by her husband's mediocrity and negligence, as well as Master Bai's unwelcome sexual advances. Haida chooses to take charge of her life by committing suicide. She has chosen to act in a responsible way in times of crisis by claiming full responsibility for the mistakes committed. Although Lida has chosen to stay with her husband and starts her life afresh while Haida has chosen to leave her husband and ends her life at the end, both women are presented as dignified women with a strong sense of morality and integrity. As evidenced in the two Yue adaptations, both women have placed self-righteousness and goodness highest within their own moral system. They celebrate Lida and Haida's moral responsibility and affirm the importance of moral goodness and integrity of the self in the process of individuation and the fashioning of the female self.

\author{
Terry Siu-Han Yip \\ terryyip@hkbu.edu.hk \\ Department of English Language and Literature \\ OEW 1115, OEN Hall Building, \\ Ho Sin Hang Campus, \\ Hong Kong Baptist University, \\ 224 Waterloo Road, Kowloon Tong, \\ HONG KONG
}

\title{
References
}

Bradford, L. M. 2007. Women in Reality: A Rhetorical Analysis of Three of Henrik Ibsen's Plays in order to Determine the Most Prevalent Feminist Themes. MA Thesis, Wichita State University.

Butler, J. 1990. Gender Trouble: Feminism and the Subversion of Identity. New York: Routledge.

Chen, Maoqing, Weichun Liu. 2011. On the Adaptation of The Lady from the Sea.Shanghai Theatre, Vol. 1, 20-21.

Finney, G. 1994. Ibsen and Feminism. - J. McFarlane, ed., The Cambridge Companion to Ibsen. Cambridge: Cambridge University Press, 89-105. 
Cultural Assimilation

He, Chengzhou. 2001-2002. Hedda and Bailu: Portraits of Two "Bored" Women. Comparative Drama, Vol. 35, Nos. 3/4 (Fall/Winter), 447-463.

Hemmer, B., Ystad, V., eds. 1988. Contemporary Approaches to Ibsen. Volume VI. Oslo: Norwegian University Press.

Ibsen, H. 1986. The Lady from the Sea. - H. Ibsen, A Doll's House and Other Plays. Trans. Peter Watts. Harmonsdworth: Penguin, 233-330.

Jin Jiang. 2009. Women Playing Men: Yue Opera and Social Change in Twentieth-Century Shanghai . Seattle: University of Washington Press.

McFarlane, J. 1960-1977. The Oxford Ibsen. Oxford: Oxford University Press.

McFarlane, J., ed. 1994. The Cambridge Companion to Ibsen. Cambridge: Cambridge University Press.

Moi, T. 2006. Henrik Ibsen and the Birth of Modernism: Art, Theater, Philosophy. Oxford: Oxford University Press.

Qing, Yun. 2010. Yue Opera Lady of Ocean Fail to Adopt Local climate. - Shanghai Theatre, Vol. 11, 32.

Taylor, Ch. 1991. The Ethics of Authenticity. Cambridge, MA: Harvard University Press.

Templeton, J. 1997. Ibsen's Women. Cambridge: Cambridge University Press.

Wu, Zhonghui, Shuhua Zuo. 2011. Secai banlan Zhingxi gebi: Yueju Haishang furen di shier jie Zhongguo Shanghai guoji yishujie xianyan ji. - Juzuojia, 2 (2011), 78-81.

Ye, Ning. 2011. Yibu yuanzhi yuanwei di Zhongguo Yueju: ping Yueju Haishang furen.Sichuan xiju, 143 (2011), 20-21.

Yun, Fu. 2010. Yihua jiemu cui chun yan: $\tan Y u e j u$ Haishang furen zhong xushuzhe di yishu chuan xiang. - Juzuo jia, 4, 98-100.

Zhang, Xinying. 2007. Chuancheng yu chaoyue: tan Yueju Xin bi tian gao de mosheng hua xiaoguo. - Ju zuojia, 4, 73-76. 